Journal of Management and Business Aplication

\title{
PURCHASE DECISION BETWEEN CONSUMER LOYALTY AND BRAND IMAGE
}

\author{
Kasiman $^{1}$ \\ Anastasia Maria $\mathbf{H}^{2}$ \\ Higher Education of Economic Mandala \\ E-mail: kasiman.skep@yahoo.com
}

\begin{abstract}
This study aims to determine and analyze the effect of consumer loyalty and brand image on seafood food purchasing decisions. The analytical tool used in this study is multiple linear regression analysis, T-Test and F-Test and Determination Coefficient. With SPSS The results of the research show that partially consumer loyalty and brand image influence the decision to buy seafood. Likewise, the results of other hypothesis tests indicate that simultaneously the independent variable of consumer loyalty and brand image influences buying decisions. Thus the results of this hypothesis test are in line with several previous studies. Consumer loyalty is the commitment of customers to a brand, store, or supplier based on the very positive nature of long-term purchases, whereas brand image states that a brand has strong roots when the brand is associated with values that represent or are desired by consumers.
\end{abstract}

Keywords : Customer Loyalty, Brand Image, Purchase Decision.

\section{INTRODUCTION}

Engel (1994: 3) states that consumer behavior is an action that is directly involved in getting, consuming, and consuming products and services, including the decision process that precedes and follows these actions. Consumers in making purchasing decisions on a product can be influenced by product quality, product prices, product advertisements, and others. The things that are inherent in these products that will form a brand image of consumers.

Loyal customers are those who are very satisfied with certain products and services, so they have the enthusiasm to introduce it to anyone they know. In the next stage, these loyal customers will expand their "loyalty" to other products made by the same manufacturer. And in the end they are consumers who are loyal to certain producers or companies forever. Philip Kotler (2001) states that high loyalty is a customer who makes a purchase with a percentage increasing in certain companies than other companies.

Purchasing decisions by consumers are decisions that involve perceptions of quality, value, and price. Consumers not only use price as an indicator of quality, but also as an indicator of costs incurred in exchange for product models or product benefits. In the culinary field, for example, there are other indicators that will influence purchasing decisions, namely taste. Brand image also 
plays an important role in influencing purchasing decisions.

Some studies also underlie the background of this research include; Musay (2013) states that brand image consisting of corporate image, user image, and product image together have a significant influence on purchasing decisions. Based on the test results it is known that the variable company image and product image have a significant effect, while the user image variable has a positive but not significant effect. The method used in this research is multiple linear regression analysis. Ekawati (2014) states that the most influential variable on purchasing decisions is product quality, followed by brand image and the last is price perception. Hypothesis testing using $\mathrm{t}$ test shows that product quality, price perception, and brand image have a positive and significant effect on purchasing decisions. The method used in this research is multiple linear regression analysis. Likewise, Lasander's (2013) study states that brand image, product quality, and promotion together have a significant effect on customer satisfaction. From the results of the $t$ test, the hypothesis which states that the alleged brand image, product quality, and promotion variables partially affect consumer satisfaction. The method used in this research is multiple linear regression analysis.

From the description above, the writer wants to find out how much influence customer loyalty and brand image have on seafood purchasing decisions in the city of Jember.

\section{Conceptual Framework}

The following is an illustration of the direction of problem solving presented in the form of a conceptual framework to facilitate the discussion and analysis.

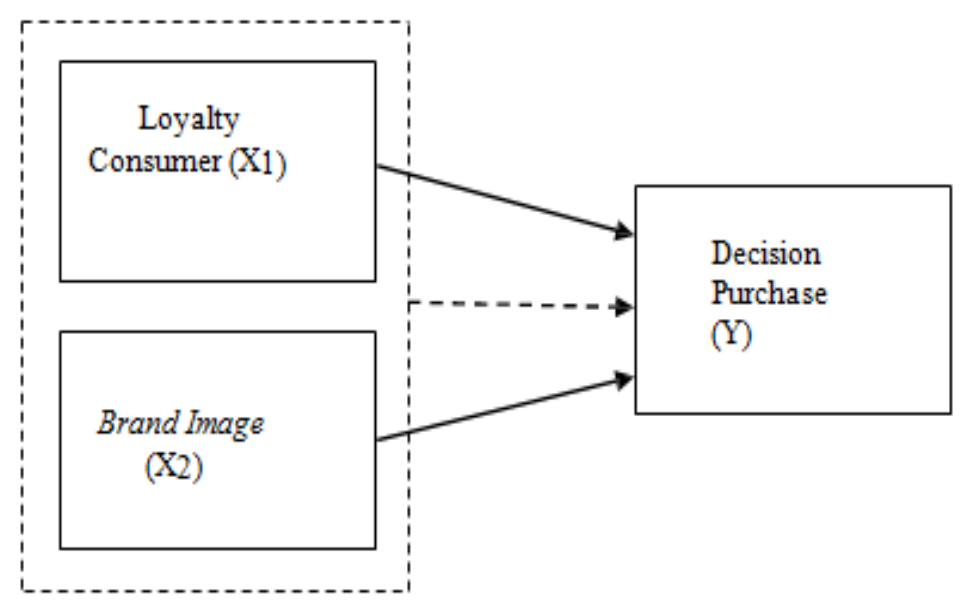

\section{Fig.1 Conceptual Framework}

\section{Hypothesis}

Based on the opinion of Tjiptono (2000: 110) consumer loyalty is a customer commitment to a brand, store, or supplier based on the very positive nature of longterm purchases, the following hypothesis is obtained:

H1: Consumer loyalty influences purchasing decisions.

Based on previous research from Fransisca Paramitasari Musay (2013) which states that brand image influences purchasing decisions, the following hypothesis is obtained:

$\mathrm{H} 2$ : Brand image influences purchasing decisions.

Based on the opinion of Aaker (1996) loyalty has a level called the pyramid of loyalty, which is ideally hierarchical. In addition to loyalty, brand image also influences purchasing decisions. According to Aaker (2000: 53-72) a brand has strong roots, when the brand is associated with values that represent or are desired by 
consumers. Based on this theory, a hypothesis is obtained:

H3: Consumer loyalty and brand image influence the decisio purchase.

\section{RESEARCH METHODS}

\section{Research Subject}

This research was conducted at the "Cak Sis" Seafood Resto, located at Jl. Kartini 64 - Jember. The object of this research is in the culinary field and has been established since 2014 .

\section{Population and Samples}

The population in this study are the people who make purchases at the "Cak Sis" Seafood Restaurant in Jember. The sampling method that will be used in this study is purposive sampling. The purposive sampling method was chosen because consumers who came to the restaurant were very diverse, so several criteria were set as respondents' requirements. The conditions specified by the author for the respondents, include: 1). Seafood Resto consumers who are at least 20 years old, b) Seafood Resto consumers who have made purchases at least five times in the past one year. Of the 70 questionnaires distributed, only 30 questionnaires could be processed as research data because 15 questionnaires did not meet the specified sample criteria. While the remaining 25 questionnaires could not be processed because statement items were not filled / answered in full.

\section{Types of Research}

This research belongs to the type of quantitative research. Quantitative research is the measurement of quantitative data and objective statistics through scientific calculations derived from a sample of people or residents who are asked to answer a number of questions.

\section{Operational Definitions of Research Variables}

1) Loyalty

According to Tjiptono (2000: 110)

consumer loyalty is a customer commitment to a brand, store, or supplier based on the very positive nature of longterm purchases. Measurement of customer loyalty can be done by measuring the indicators that affect customer loyalty, including:

a. Repeated product purchase or service use, the measurement of which: the number of times a customer purchases a product or uses a service. This can be calculated per unit time.

b. Purchase of products or use of other services, the measurement of which is the number of times customers buy other similar products from other companies or the number of times using other similar services from other companies.

c. Recommend products or services to other people, whose measurements: have customers ever recommended products or services used and how many friends or colleagues are given recommendations.

\section{2) Brand Image (Brand Image)}

Brand image (brand image) is a series of consumer beliefs about a particular brand so that the brand association is inherent in the minds of consumers.

Indicators of brand image (brand image), include(Davidson, 1998):

a. Reputation (good name), i.e. the level or status is quite high of a particular product brand

b. Recognition, which is the level of recognition of a brand by consumers. If a brand is not known, then the product brand must be sold by relying on a low price.

c. Affinity (emotional connection), which is an emotional relationship that arises between a brand and its customer. A product with a brand that is liked by consumers will be easier to sell and a product that is perceived to have high quality will have a good reputation.

d. Brand loyalty (brand loyalty), namely how far the loyalty of consumers using products with certain brands. 


\section{3) Decision of Purchase}

According to Kotler (2002), purchasing decisions are actions of consumers to want to buy or not to a product.

Indicators of purchasing decisions, including:

a. Transactional interest, that is a person's tendency to buy products.

b. Preferential interest, that is an interest that describes the behavior of someone who has a primary preference for the product. This preference can only be replaced if something happens with the product of his preference.

c. Refrential interest, which is a person's tendency to refer products to other people.

d. Explorative interest, this interest describes the behavior of someone who is always looking for information about the product he is interested in and is looking for information to support the positive qualities of the product. (Ferdinand, 2006)

\section{Data Collection Methods}

Data collection methods are used to obtain valid data in answering all issues related to research problems. In this research, there are three types of methods used, including observation, interview and literature study.

\section{Data Analysis Method \\ a) Test Validity}

Validity test is used to measure the validity of a questionnaire. The validity test in this study uses Pearson's Product Moment Coefficient $r$. If $r$ count $>r$ table then the statement is declared valid, this means that the indicators used in this study are eligible to be used as data collection. Conversely, if $r$ count $\leq$ rtable, the statement declared invalid.

\section{b) Reliability Test}

The reliability test is used to measure the consistency of the measurement results from the questionnaire in repeated use. The reliability test in this study uses Cronbach Alpha, ie if the Cronbach Alpha coefficient> 0.7 then the statement is declared reliable. Conversely, if the Cronbach Alpha coefficient $\leq 0.7$, the statement declared unreliable.

\section{c) Normality Test}

Normality test is used to find out whether the data in the resulting regression equation is normal or abnormal. If probability> 0.05 then the distribution of the population is normal whereas if probability $<0.05$ then the population is not normally distributed.

\section{d) Multicollinearity Test}

Multicollinearity test is used to find out whether in a regression model found a correlation between independent variables (Independent). A good regression model that does not occur correlation between independent variables. If the VIF value> 10 can be said to be free from multicollinearity, whereas if the reverse is the case the regression model has multicollinearity problems.

\section{e) Heteroscedasticity Test}

Heteroscedasticity test is used to test whether the regression model occurs the difference from the residuals of one observation to another. Heteroscedasticity is tested using a plot graph, if the points that form a certain pattern are regular (wavy, widened, then narrowed), then heteroscedasticity has been declared. Based on the scatter plot graph, it appears that the points spread and do not form a particular pattern, it can be concluded that there is no heteroscedasticity disorder in this regression model.

\section{RESULT ANALYSIS}

\section{Test Validity and Reliability a. Validity Test Results}

Validity test is used to measure the validity or validity of a questionnaire. Test to determine significant or insignificant by 
comparing the calculated $\mathrm{r}$ value with rtable value $(\alpha=0.05)$. If a data has a significance value $<0.05$ then the question / statement item is said to be valid.

Based on the table of validity test results, it is known that the significance value of all $X$ variables and $Y$ variables shows the number $<0.05$. Therefore, all items in the questionnaire were declared valid.

\section{b. Reliability Test Results}

Instrument reliability illustrates the stability and consistency of the measuring instruments used. A measuring instrument is said to have good reliability if the measuring instrument or instrument always gives the same results even though it is used many times by the same researcher or different researchers. Reliable instruments will produce data that matches the real conditions. A construct or variable is said to be reliable if it gives a Cronbach alpha value> 0.60 .

Based on the reliability test results table, it is known that all constructs or variables show a Cronbach's alpha value> 0.60 . Thus, it can be concluded that all measuring instruments used are reliable.

\section{Test Classic Assumptions a. Normality Test Results}

Based on the Kolmogorov-Smirnov Test output above, a significance value of 0.645 is known from the loyalty variable, 0.420 from the brand image variable, and 0.250 from the purchase decision variable. The significance value of each variable shows a number greater than $\alpha(\alpha=0.05)$, so it can be concluded that the tested data are normally distributed.

\section{b. Linearity Test Results}

Based on the ANOVA Table output above, it is known that the Sig.Linearity value on the relationship between loyalty variables with purchase decisions is 0,000 and on the relationship between brand image variables with purchasing decisions also shows the number 0,000 . Because the significance value is greater than 0.05 , it can be concluded that there is a linear relationship of each of the loyalty variables and brand image with the purchase decision variable.

\section{c. Multicollinearity Test Results}

Based on the Coefficients output above, the Tolerance value on the two dependent variables shows a number of more than 0.1 which is equal to 0.595 and the VIF value indicates a number less than 10 , so it can be concluded that there is no multicollinearity problem with the tested data.

\section{d. Autocorrelation Test Results}

Based on the Summary Model output above, it is known that the Durbin-Watson value is 2.184 . That value is then compared with the Durbin-Watson table value of 5\% significance $(\alpha=0.05)$. The number of samples is $30(\mathrm{~N}=30)$, the number of independent variables as much as $2(\mathrm{~K}=2)$ is used to see the $\mathrm{dL}$ and $\mathrm{dU}$ values in the Durbin-Watson table. From these data, we obtain the value of $\mathrm{dL}=1.283$ and $\mathrm{dU}=$ 1.566. It can be seen that the value of $d$ (Durbin-Watson) of 2.184 lies in the area of $\mathrm{dU}<\mathrm{d}<4-\mathrm{dU}(1,284<2,184<2,434)$ then $\mathrm{H} 0$ is accepted. The conclusion is that there is no autocorrelation in the regression model.

\section{c. Heteroscedasticity Test Results}

Based on the Coefficients output above, it is known that the significance value on the loyalty variable is 0.762 and on the brand image variable is 0.889 . The significance value of the two variables shows a number greater than 0.05 so it can be concluded that there was no heteroscedasticity in this regression equation.

\section{Multiple Linear Regression Analysis}

This analysis is used to determine the direction of the relationship between the independent variable with the dependent variable whether each independent variable is positively or negatively related, and to 
predict the value of the dependent variable increased or decreased.

if the value of the independent variable has

Table 1. Results of Multiple Linear Regression Analysis

Coefficients $^{\mathrm{a}}$

\begin{tabular}{|c|c|c|c|c|c|c|c|c|}
\hline \multirow[b]{2}{*}{ Mode } & & \multicolumn{2}{|c|}{ Unstandardized Coefficients } & $\begin{array}{l}\text { Standardized } \\
\text { Coefficients }\end{array}$ & \multirow[b]{2}{*}{$t$} & \multirow[b]{2}{*}{ Sig. } & \multicolumn{2}{|c|}{$95,0 \%$ Confidence Interval for B } \\
\hline & & B & Std. Error & Beta & & & Lower Bound & Upper Bound \\
\hline \multirow[t]{3}{*}{1} & (Constant) & $-3,786$ & 2,506 & & $-1,511$ &, 142 & $-8,928$ & 1,356 \\
\hline & loyalitas & 802 &, 231 &, 507 & 3,469 &, 002 &, 328 & 1,276 \\
\hline & brand image & 308 & 116 & 388 & 2,654 &, 013 & ,070 &, 546 \\
\hline
\end{tabular}

a. DependentVariable: keputusan pembelian

Based on output coefficients, the form of multiple linear regression equations is as follows:

$\mathrm{Y}=-3,786+0,802 \mathrm{X} 1+0,308 \mathrm{X} 2+\mathrm{e}$

Caption :

a. Constants are negative. This means that if loyalty and brand image are constant, then the purchase decision is negative, meaning that potential customers do not choose to buy the product.

b. The value of b1 partially indicates that loyalty influences the purchasing decision of 0.802 . The higher the value of loyalty, the higher the value of the

purchase decision because it has a direct effect.

c. Partially b2 value indicates that brand image influences the purchasing decision of 0.308 . The higher the value of the brand image, the higher the value of the purchase decision.

4. Analysis of the coefficient of determination

Analysis of the coefficient of determination (R2) is used to find out how much the percentage contribution of the influence of the independent variables simultaneously on the dependent variable.

Table 2. Determination Coefficient Test Results $\left(\mathbf{R}^{2}\right)$

\begin{tabular}{|c|c|c|c|c|c|c|c|c|c|}
\hline \multicolumn{10}{|c|}{ Model Summary } \\
\hline \multirow[b]{2}{*}{ Model } & \multirow[b]{2}{*}{$R$} & \multirow[b]{2}{*}{ RSquare } & \multirow[b]{2}{*}{ Adjusted R Square } & \multirow{2}{*}{$\begin{array}{l}\text { Stcl Error of the } \\
\text { Estimate }\end{array}$} & \multicolumn{5}{|c|}{ Change Statistics } \\
\hline & & & & & RSquare Change & FChange & difl & dit? & Sig. F Change \\
\hline 1 & $811^{\circ}$ & .657 & .632 & 1,741 & .657 & 25,868 & 2 & 27 & 000 \\
\hline
\end{tabular}

Based on the Summary Model output, the coefficient of determination is known (adjusted R2) of 0.632. The magnitude of the coefficient of determination is equal to $63.2 \%$. This figure implies that brand loyalty and loyalty contributed to the purchase decision of $63.2 \%$. While the rest $100 \%$ $63.2 \%=36.8 \%$ ) is influenced by other variables outside this regression model.

\section{Results T-Test}

$\mathrm{T}$ test was conducted to determine the effect of partially independent variables on the dependent variable, whether the effect is significant or not. Variables are stated to have a significant effect if the significance value of the variable is less than 0.05 . 
Table 3. Test Results $t$

Coefficients $^{\mathrm{a}}$

\begin{tabular}{|c|c|c|c|c|c|c|c|c|}
\hline \multirow[b]{2}{*}{ Mode } & & \multicolumn{2}{|c|}{ Unstandardized Coefficients } & $\begin{array}{l}\text { Standardized } \\
\text { Coefficients }\end{array}$ & \multirow[b]{2}{*}{$t$} & \multirow[b]{2}{*}{ Sig. } & \multicolumn{2}{|c|}{$95,0 \%$ Confidence Interval for B } \\
\hline & & $B$ & Std. Error & Beta & & & Lower Bound & Upper Bound \\
\hline \multirow[t]{3}{*}{1} & (Constant) & $-3,786$ & 2,506 & & $-1,511$ &, 142 & $.8,928$ & 1,356 \\
\hline & loyalitas &, 802 & 231 &, 507 & 3,469 &, 002 & 328 & 1,276 \\
\hline & brand image & 308 &, 116 & 388 & 2,654 &, 013 &, 070 &, 546 \\
\hline
\end{tabular}

a. Dependent Variable: Keputusan pembelian

Based on the Coefficients output, it is known that the significance value of the loyalty variable is 0.002 and the brand image variable is 0.013 . Both of the independent variables have significance values less than 0.05 . It can be concluded that loyalty and brand image have a partial effect on purchasing decisions.

\section{Results F- Test}

$F$ test is performed to determine the effect of independent variables simultaneously or simultaneously on the dependent variable, whether the effect is significant or not. Variables are stated to have a significant effect if the significance value of the variable is less than 0.05 .

Table 4. Test Results F

ANOVA $^{\mathrm{a}}$

\begin{tabular}{|ll|r|r|r|r|r|}
\hline Model & & Sum of Squares & df & Mean Square & \multicolumn{1}{c|}{ F } & \multicolumn{1}{c|}{ Sig. } \\
\hline 1 & Regression & 156,825 & 2 & 78,412 & 25,868 &, $000^{\mathrm{b}}$ \\
& Residual & 81,842 & 27 & 3,031 & & \\
& Total & 238,667 & 29 & & & \\
\end{tabular}

a. Dependent Variable: keputusan pembelian

b. Predictors: (Constant), brand image, loyalitas

Based on Anova output, it is known that the significance value shows 0,000 . The significance value is smaller than 0.05 so it can be concluded that loyalty and brand image have an effect simultaneously or simultaneously on purchasing decisions.

\section{INTERPRETATION}

From the results of data processing using the analysis method that has been done as well as a description of the results of the study, the interpretation is obtained as follows:
1. Effect of Loyalty on Purchasing Decisions

In the analysis method that has been done, the results show that loyalty has a partial effect on purchasing decisions. This is indicated by the $\mathrm{t}$ test to see whether the effect is significant or not. In the t test, it is known that the significance value of the loyalty variable is 0.002 which means that the variable has a significance value less than 0.05 so that it is partially declared influential.

In the results of the questionnaire, the respondents' responses to the items of the loyalty variable also stated that $43.3 \%$ of the total number of respondents stated that they sometimes buy seafood products at Cak Sis Resto and other restaurants. Then $63.3 \%$ said they recommend Cak Sis seafood products to friends, relatives, and colleagues. And 66.7\% 
stated that they always invite at least one friend / relative / colleague when buying Cak Sis seafood products.

Based on the facts in the field, the significance of loyalty can be influenced by the quality, taste, service, and comfort of Resto Cak Sis which does not change from time to time. The results of this analysis are also in line with the opinion of Tjiptono (2000: 110) about loyalty which states that loyalty influences purchasing decisions.

\section{The Effect of Brand Image on Purchasing Decisions}

In the analysis method that has been done, the results are obtained that the brand image has a partial influence on purchasing decisions. This is indicated by the $t$ test to see whether the effect is significant or not. In the $\mathrm{t}$ test, it is known that the significance value of the loyalty variable is 0.013 which means that the variable has a significance value less than 0.05 so that it is partially declared influential.

In the results of the questionnaire, respondents' responses to the brand image variable items also stated $36.7 \%$ of the total number of respondents agreed that the Cak Sis restaurant was the best seafood restaurant in Jember. 50\% agreed that almost all people in the city of Jember were familiar with Cak Sis restaurant and the majority knew through signboards and mass media. Then $63.3 \%$ stated that Cak Sis restaurant can always make consumers want to come again another time, and $50 \%$ feel that sometimes there is an increase in prestige when eating at $\mathrm{Cak}$ Sis restaurant.

Based on the facts on the ground, the significance of brand image can be influenced by reputation based on the consistency of good name that is still maintained. In addition, the good name of Cak Sis Resto will increase consumer prestige.

The results of this analysis are also in line with the results of previous studies from Musay (2013) and Ekawati (2014) which state that brand image influences purchasing decisions.
3. Effect of Loyalty and Brand Image on Purchasing Decisions

In the analysis method that has been done, the results show that loyalty and brand image have a simultaneous influence on purchasing decisions. This is indicated by the $F$ test to see whether the effect is significant or not. In the F test, it is known that the significance value indicates 0,000 which means that the variable has a significance value of less than 0.05 so that it is simultaneously stated to be influential.

In the results of the questionnaire, respondents' responses to the purchase decision variable items also stated $40 \%$ of the total number of respondents sometimes preferred seafood products at Cak Sis restaurant compared to other seafood restaurants in Jember. Furthermore, 40\% stated that they always make Cak Sis seafood products as the main choice. $46.7 \%$ make Cak Sis restaurant as the main reference for seafood restaurant to friends / relatives / colleagues. And $33.3 \%$ of the respondents, some of whom have tried the entire seafood menu at the Cak Sis restaurant.

Based on facts in the field, the significance of loyalty and brand image can influence consumer purchasing decisions on seafood products at Cak Sis Resto. The results of this analysis are also in line with the opinion of Aaker (1996) about the pyramid of loyalty which states that loyalty and brand image influence purchasing decisions.

\section{CONCLUSION}

Based on the analysis conducted on the Influence of Consumer Loyalty and Brand Image on Seafood Food Purchasing Decisions at the Jember "Cak Sis" Sea Food Resto, it was concluded that loyalty and brand image have a significant and partially significant influence on purchasing decisions. Significance of loyalty is caused by repeated purchases of products or services, purchases of products or use of other services, and recommending products or services to others. While the significance of brand image is caused by good name, recognition, emotional 
connection, and brand loyalty. The significance of loyalty and brand image is caused by the tendency to buy a product, the main preference for a product, the tendency to refer the product to others, and the behavior that is always looking for information about the product of interest.

\section{IMPLICATIONS}

Based on the research results, Cak Sis Resto should be able to maintain consumer loyalty and brand image of Cak Sis Resto because. It has been concluded that the loyalty and brand image variables have an effect on consumer's decision to buy seafood at Resto Cak Sis. With this, other advantages can be increased, for example in terms of service quality, taste, and so on so that consumer loyalty towards Cak Sis Resto and the brand image of Resto Cak Sis can be maintained.

\section{REFERENCES}

Aaker, D. A. 1996. Building Strong Brands. New York: The Free Press.

Aaker, David A, dan Joachimsthaler, Erich. 2000. Brand Leadership. New York: The Free Press.

Algifari. 2000. Analisis Regresi :Teori, Kasus dan Solusi. Yogyakarta: BPFE Ekawati, Desi Retno. 2014. Analisis Pengaruh Kualitas Produk, Persepsi Harga, dan Citra Merek Terhadap Keputusan Pembelian. Skripsi. Fakultas Ekonomi dan Bisnis Universitas Diponegoro Semarang.

Engel, James F., Roger D. Blackwell, Paul W. Miniard. 1994. Perilaku Konsumen. Jilid I. Edisi Keenam. Jakarta: Binarupa Aksara.

Evawati. 2012. Pengaruh Kualitas Produk dan Citra Merek (Brand Image) McDonald Terhadap Kepuasan Konsumen. Skripsi. Fakultas Ekonomi dan Bisnis Universitas Mercu Buana.

http://ketutsumada.blogspot.co.id/2012/04/ kepuasan-dan-loyalitaspelanggan.html http://persahabatandanpersaudaraan.blogsp ot.com/2012/05/perekonomian-

http://114.57.38.118/corporate_actions/new _info_jsx/jenis_informasi/01_1

aporan_keuangan/04_Annual\%20Report/20 11/GGRM/GGRM_AR\%2020

11.pdfindonesia-dalamera.html?zx=aeebe1484e5b37e

http://tipulu-

twt.blogspot.co.id/2013/06/analisispe ngaruh-brand-image-citra.html

http://www.maribelajarbk.web.id/2015/07/p engertian-metode-penelitian-

kuantitatif.html?m=1

http://www.pendidikanekonomi.com/2012/ pengertian-brand-image.html? $\mathrm{m}=1$

Keller, KL. 2003. Strategic Brand Management, Building Measurement and Managing Brand Equity. Upper Sadle River: NJ Pearson Education International.

Kotler, Philip. 2001. Manajemen Pemasaran di Indonesia : Analisis, Perencanaan, Implementasi dan Pengendalian. Jakarta: SalembaEmpat.

Kotler, Philip. 2004. Manajemen Pemasaran 2. Edisi Millenium. Jakarta: PT. Ikrar Mandiri.

Lasander, Christian. 2013. Pengaruh Citra Merek, Kualitas Produk, dan Promosi Terhadap Kepuasan Konsumen Pada Makanan Tradisional. Skripsi. Fakultas Ekonomi dan Bisnis Universitas Sam Ratulangi Manado.

Musay, Fransisca Paramitasari. 2013. Pengaruh Brand Image Terhadap Keputusan Pembelian. Skripsi. Fakultas Ilmu Administrasi Universitas Brawijaya.

Nugroho, FaridYanuar. 2011. Pengaruh Citra Merekdan Kepuasan Pelanggan Terhadap Loyalitas Konsumen. Skripsi. Fakultas Pertanian Universitas Pembangunan Nasional "Veteran" Yogyakarta.

Priyatno, Duwi. 2013. Analisis Korelasi, Regresi, dan Multivariate dengan SPSS. Yogyakarta: Gava Media. 
Setiadi, Nugroho J. 2008. Perilaku Konsumen: Konsep dan Implikasi untuk Strategi dan Penelitian Pemasaran. Jakarta: Kencana.

Sugiyono. 2008. Metode Penelitian Kuantitatif, Kualitatif dan $R \& D$. Bandung: Alfabeta.
Sujarweni, $\quad$ V.Wiratna. 2015. Metodologi Penelitian - Bisnis \& Ekonomi. Yogyakarta: Pustaka Baru Press.

Sunyoto, Danang. 2013. Metodologi Penelitian Akuntansi. Cetakan 1. Bandung: Refika Aditama. 